\title{
UPAYA PENANGANAN PEMBIAYAAN MUDHARABAH BERMASALAH DI KSPS BMT LOGAM MULIA KLAMBU GROBOGAN
}

\author{
Lu'lua Nur Rizkianing Tyas ${ }^{1}$, Jaenal Arifin ${ }^{2}$ \\ 1 Institut Agama Islam Negeri Kudus \\ $\triangle$ nur_tyas@gmail.com
}

\begin{abstract}
According to Saeed Mudharabah Financing Practices will encounter many problems in Islamic financial institutions, one of which is non-performing financing. This study seeks to describe the practice of mudharabah financing and the efforts to handle problematic mudharabah financing at KSPS BMT Logam Mulia. This study uses a qualitative method with a field research approach. To track data, researchers conducted observations and interviews as well as documentation according to the themes discussed. The informants selected by the researchers were managers and employees of the KSPS BMT Logam Mulia Klambu to conduct interviews in the data search process. First, the practice of mudharabah financing at KSPS BMT Logam Mulia Klambu runs as the mudharabah practice in sharia financial institutions, both banks and Islamic cooperatives. Second, the settlement of problematic mudharabah financing. KSPS BMT Logam Mulia prioritizes the principle of kinship and tries to avoid collateral execution or legal channels.
\end{abstract}

Keywords : KSPS BMT Logam Mulia; Troubled Mudharabah Financing; Sharia Cooperative

\section{LATAR BELAKANG}

Istilah koperasi di Indonesia telah terlebih dahulu dikenal masyarakat dan merupakan dianggap sebagai lembaga keuangan alternatif, karena dinilai proses pelayanan yang cepat dan mudah (Sofian, 2018). Sedangkan istilah koperasi syariah muncul pada tahun 2004, dibuktikan dengan Keputusan Menteri (Kepmen) Koperasi dan UKM Republik Indonesia Nomor 91/Kep/M.KUKM/IX/2004 tanggal 10 September 2004 Tentang Petunjuk Pelaksanaan Kegiatan Usaha Koperasi Jasa Keuangan Syariah.

Menurut Burhanuddin (2013) Koperasi sendiri merupakan institusi keuangan yang berorientasi pada tercapainya kemandirian pengguna jasa, bukan kumpulan modal seperti halnya badan usaha lainnya yang beroperasi pada investor. Salah satu koperasi syariah yang berusaha meningkatkan kesejahteraan masyarakat ekonomi lemah melalui kegiatan penghimpunan dana dan pembiayaan anggota adalah koperasi simpan pinjam syariah (KSPS) BMT Logam Mulia. Dalam proses pembiayaan KSPS BMT Logam Mulia sebagai penyediaan uang yang mempunyai kesepakatan dengan pihak yang dibiayai, sehingga pihak yang dibiayai mempunyai kewajiban untuk mengembalikan uang tersebut setelah jangka waktu tertentu dengan margin atau bagi hasil (Asiyah, 2015). Sedangkan produk pembiayaan yang menjadi andalan KSPS BMT Logam Mulia adalah akad mudharabah, pada posisi ini pihak KSPS BMT Logam Mulia berperan sebagai 
sebagai investor pemilik dana (shahibul maal) dan pihak lain sebagai pengelola dana (mudharib) (Al-Jambi, 2019). Menurut Abdullah Saeed praktek pembiayaan mudharabah pada lembaga keuangan syariah dipastikan terdapat kendala dimulai dari modal, manajemen, masa berlakunya kontrak, jaminan, prinsip bagi hasil (profit and Loss Sharing) yang berbeda dengan konsep mudharabah yang berkembang dalam ilmu fiqh (Qomar, 2018).

Untuk mengantisipasi kendala tersebut KSPS BMT Logam Mulia dalam penyaluran dana penbiayaan harus memperhatikan karakter anggota, analisis keuangan anggota, struktur modal, kemampuan produksi, siklus usaha, dan jaminan. Berdasarkan hasil observasi pada KSPS BMT Logam Mulia Klambu yang beralamat di kecamatan Klambu, Jl. Raya Klambu No. 27 Klambu, Grobogan, Telp. (0292) 4274025 diperoleh data jumlah transaksi pembiayaan mudharabah sebagai berikut:

Table 1.

Jumlah Transaksi Pembiayaan Akad Mudharabah KSPS BMT Logam Mulia

\begin{tabular}{|c|l|l|l|}
\hline Tahun & $\begin{array}{l}\text { Periode } \\
\text { Bulan }\end{array}$ & $\begin{array}{l}\text { Mudharabah } \\
\text { Lancar }\end{array}$ & $\begin{array}{l}\text { Mudharabah } \\
\text { Masalah }\end{array}$ \\
\hline 2018 & Januari-Juni & 180 & 35 \\
\hline 2018 & $\begin{array}{l}\text { Juli- } \\
\text { November }\end{array}$ & 187 & 31 \\
\hline
\end{tabular}

Dari tabel tersebut terdapat sesuatu yang menarik adalah penurunan akad mudharabah bermasalah, meskipun tidak begitu signifikan mengalami penurunan, namun apabila dibiarkan akan mengancam kesehatan keuangan KSPS BMT Logam Mulia Klambu Grobogan. Untuk itu peneliti menilai perlu penelusuran lebih lanjut upaya penanganan pembiayaan mudharabah bermasalah yang dilakukan KSPS BMT Logam Mulia, karena melihat urgensi pembiayaan mudharabah dalam membantu masyarakat muslim dalam menjalankan usahanya.

\section{TEORI DAN METODE}

\subsection{Pembiayaan Syariah}

Menurut kamus pintar ekonomi syariah, pembiayaan diartikan sebagai penyediaan dana atau tagihan yang dipersamakan dengan itu berupa: transaksi bagi hasil dalam bentuk mudharabah dan musyarakah, transaksi sewa-menyewa dalam bentuk ijarah atau sewa beli dalam bentuk ijarah muntahiyah bit tamlik, transaki jual beli dalam bentuk piutang murabahah, salam, dan istishna, transaksi pinjam meminjam dalam bentuk piutang qardh, dan transaksi sewa menyewa 
jasa dalam bentuk ijarah untuk transaksi multi jasa berdasarkan persetujuan atau kesepakatan antara bank syariah serta atau UUS dan pihak lain yang mewajibkan pihak yang dibiayai dan atau diberi fasilitas dana untuk mengembalikan dana tersebut setelah jangka waktu tertentu dengan imbalan ujrah, tanpa imbalan, atau bagi hasil.

Pembiayaan atau financing adalah pendanaan yang diberikan oleh suatu pihak kepada pihak lain untuk mendukung investasi yang telah direncanakan, baik dilakukan sendiri maupun lembaga

\subsection{Metode Penelitian}

Penelitian ini menggunakan motede kualitatif dengan pendekatan penelitian lapangan (field research). Penelitian ini berusaha mengurai praktek pembiayaan mudharabah dan upaya penganganan pembiayaan mudharabah bermasalah di KSPS BMT Logam Mulia.

Untuk melacak data, peneliti melakukan observasi dan wawancara sekaligus dokumentasi sesuai dengan tema yang dibahas. Informan yang dipiliholeh peneliti adalah manajer dan karyawan KSPS BMT Logam Mulia Klambu untuk melakukan wawancara dalam proses pencarian data.

\section{HASIL DAN PEMBAHASAN}

\section{Profil KSPS BMT Logam Mulia}

Latar belakang berdirinya BMT Logam Mulia berawal dari sejumlah tokoh masyarakat, para ulama yang dipelopori oleh H. Mustamir, pada tanggal 10 Agustus 2001 berkumpul dan menggagas suatu lembaga yang menangani simpan pinjam yang berpolakan Syari'ah. Tepat pada tanggal 25 Agustus 2001 terbentuk pendiri sekaligus membuat nama lembaga serta draf Anggaran Dasar dan Rumah Tangga. Nama lembaga disepakati dengan nama "KSPS BMT Logam Mulia" dan disampaikan kepada Kepala Kantor Koperasi dan UKM Kabupaten Grobogan untuk pengesahan.

KSPS BMT Logam Mulia mulai beroperasi sejak tanggal 1 Oktober 2001 setelah mendapat badan hukum dan Menteri Negara Koperasi Pengusaha Kecil dan menengah Republik Indonesia No.112/BH/KDK.11- 14/IX/2001 tanggal 15 September 2001. Sesuai dengan anggaran Dasar Modal Perusahaan ini sebesar Rp 225.000.000 (dua ratus dua puluh lima juta rupiah) yang dimulai oleh 25 (dua puluh lima) orang anggota. Berlokasi di Jl. Raya Klambu No. 10 Kec. Klambu Kab. Grobogan.

Pada tanggal 12 Februari 2002 KSPS BMT Logam Mulia membuka kantor di kecamatan Grobogan, yang beralamatkan di Jl. P. Puger No. 69 Grobogan dengan jumlah karyawan 4 orang, dan dalam rangka mendekatkan pelayanan terhadap calon anggota yang bergabung dari luar kecamatan atau kabupaten, maka pada tanggal 13 Maret 2002 dibukalah Kantor Kas Pelayanan di Babalan Kalirejo Kecamatan Undaan Kabupaten Kudus yang beralamatkan Jl. Raya Purwodadi-Kudus KM 15, dengan jumlah pengelola 4 orang. Dalam waktu dua bulan dipandang perlu untuk membuka 
Kantor Pelayanan di Kecamatan Undaan pada tanggal 13 Mei 2002 dengan alamat Jl. Raya-Purwodadi Kudus KM 7, dengan karyawan 4 orang.

Pada tanggal 2 Juli 2005 KSPS NMT Logam Mulia membuka kantor di kecamatan Gubug, dengan alamat Jl. Bhayangkara No. 64 kecamatan Gubug kabupaten Grobogan dengan jumlah karyawan 4 orang. Terakhir pada tanggal 1 Mei 2011, KSPS BMT Logam Mulia mendirikan di kecamatan Dawe yang beralamtkan di Jl. Colo-Kudus KM 12 Lau kecamatan Dawe kabupaten Kudus dengan karyawan 4 orang.

Usaha pendirian koperasi tersebut merupakan salah satu bentuk upaya membantu program pemerintah dalam mengatasi kebutuhan pelayanan masyarakat golongan ekonomi lemah dan pengusaha kecil secara optimal yang mayoritas ada di pedesaan yang pada giliranya ikut berperan dalam memperlancar kegiatan ekonomi pedesaan khususnya pada Kabupaten Grobogan dan sekitarnya. Disamping hal tersebut tentunya usaha KSPS BMT Logam Mulia ikut memberantas para pelepas uang yang pada waktu itu banyak beroperasi di pedesaan dengan memberi pinjaman dengan tingkat suku bunga tinggi.

KSPS BMT Logam Mulia memiliki usaha sebagaimana koperasi syariah lainya: Pertama, Menghimpun dana dari anggota dalam bentuk Simpanan Harian dan Simpanan Berjangka. Kedua, Menyalurkan dalam bentuk pembiayaan bagi pengusaha kecil atau masyarakat pedesaan (Tyas, 2018b).

\section{Praktek Pembiayaan Mudharabah di KSPS BMT Logam Mulia Klambu}

Akad mudharabah dikenal oleh masyarakat sebagai akad bagi hasil, dikarenakan dari hasil keuntungan usaha dibagi prosentasi antara shohibul maal (pihak KSPS BMT Logam Mulia) dan mudharib (pihak yang dibiayai). Selain itu akad mudharabah dikenal sebagai ciri khas akad dalam lembagai keuangan syariah, baik bank syariah maupun Industri Keuangan Non Bank (IKNB) syariah. Artinya akad mudharabah merupakan ruh adanya lembaga keuangan itu sendiri.

Dalam konteks akad mudharabah sebagai produk pembiayaan, maka dibutuhkan kehati-hatian dalam menjalankannya. Sebagaimana praktek pembiayaan mudharabah di lembaga keuangan syariah lainnya, praktek pembiayaan mudharabah di KSPS BMT Logam Mulia Klambu diperuntukkan untuk membiayai modal kerja yang diperlukan oleh nasabah, dimana KSPS BMT Logam Mulia Klambu memberikan modal sebanyak $100 \%$ dan nasabah yang menjalankan usahanya.

Untuk pembagian keuntungan diprosentasi sesuai dengan kesepakatan. Apabila rugi, kerugian tersebut ditanggung pihak KSPS BMT Logam Mulia selama kerugian ini bukan akibat dari kelalaian anggota nasabah dan apabila kerugian tersebut diakibatkan kelalaian nasabah, maka nasabah yang bertanggung jawab.

Hal tersebut sebagaimana dijelaskan oleh Bapak Bisri Musthofa selaku manajer KSPS BMT Logam Mulia Klambu sebagai berikut:

"Akad pembiayaan pada KSPS BMT Logam Mulia menggunakan akad mudharabah. Pada akad ini baik mitra maupun anggota sama-sama mendapatkan nisbahnya." 
Pada praktek pembiayaan mudharabah mengandung unsur kepercayaan, kejujuran dan keadilan, sehingga pada prakteknya tidaklah mudah dan sangat beresiko (Qomar, 2018). Menurut Friyanto (2013) dalam penelitiannya mengatakan bahwa pembiayaan mudharabah mengandung resiko antara lain: Pertama, ketidaksinkronan informasi antara kedua belah pihak. Kedua, pihak yang dibiayai atau nasabah menggunakan dana mudharabah tidak sesuai dengan isi kontrak perjanjian pembiayaan mudharabah. Ketiga, memungkinkan pihak yang dibiayai melakukan kelalaian yang disengaja. Untuk itu dibutuhkan pengawasan yang ketat dan melakukan screening kelayakan nasabah sebelum dibiayai.

Dalam penelitian Lestari \& Setiawati (2018) mengungkapkan untuk meminimalisir resiko lembaga keuangan syariah harus melakukan tahap-tahap sebagai berikut melakukan pembinaan secara teratur, yaitu dengan cara memonitoring aktif dan memonitoring pasif. Monitoring aktif, mengunjungi nasabah secara reguler dan memberikan laporan kunjungan nasabah/ call report kepada komite pembiayaan/ supervisor A/M, memantau laporan keuangan secara rutin, dan memberikan laporan kunjungan nasabah kepada bank syariah setiap akhir bulan. Bersamaan pula diberikan pembianaan dengan memberikan saran, informasi maupun pembinaan teknis yang bertujuan untuk menghindari kegagalan pembiayaan.

Dalam hal ini manager KSPS BMT Logam Mulia Klambu mengungkapkan syarat dan kriteria untuk mengajukan pembiayaan akad mudharabah sebagai berikut:

"Syarat dan kriteria untuk mendapatkan pembiayaan yaitu beragama Islam, sehat jasmani dan rohani, dewasa, pengajuan nasabah sendiri, melengkapi admistrasi. Setelah itu nasabah bisa menunggu untuk menemui marketing BMT untu proses selanjutnya."

Penerapan prinsip kehati-hatian atau diistilahkan ikhtiyati mengandung makna bahwa setiap akad dilakukan dengan pertimbangan yang matang dan dilaksanakan secara tepat dan cermat (Usanti \& Thalib, 2016). Bagi KSPS BMT Logam Mulia Klambu hal tersebut mutlak untuk dilakukan. Hal ini diwujudkan dalam analisa pembiayaan yaitu menganalisa keyakinan atas kemauan dan kemampuan calon nasabah serta kesanggupan untuk melunasi seluruh kewajiban pada waktunya. Dalam menilai layak tidaknya nasabah untuk dibiayai dengan akad mudharabah, lembaga keuangan syariah masih menggunakan $5 \mathrm{C}$ (character, capacity, capital, collateral, condition) (Kolistiawan, 2014).

Mekanisme seperti di atas sangat tergantung kecermatan marketing lending sebagai ujung tombak untuk melakukan analisa apakah nasabah tersebut layak atau tidak untuk melakukan akad mudharabah.

\section{Penyebab Pembiayan Mudharabah Macet di KSPS BMT Logam Mulia Klambu}

Sebagaimana diketahui proses pembiayaan mudharabah dilakukan dengan prinsip kehati-hatian, meskipun begitu pembiayaan mudharabah mempunyai resikoresiko yang akan terjadi dikemudian hari. Bapak Musthafa memberikan gambaran tentang resiko pembiayaan mudharabah sebagai berikut: 
"Ada beberapa risiko yang biasa kami hadapi saat menyalurkan dana pembiayaan kepada masyarakat. Risiko tersebut berupa pengembalian hutang kurang lancar bahkan cenderung macet". Klambu:

Hal tersebut dipertegas oleh Hidayati pegawai teller KSPS BMT Logam Mulia

"Biasanya risiko yang kami hadapi dalam pembiayaan mudharabah yaitu pembiayaan kurang lancar. Nasabah seringkali telat membayar bahkan menunggak berbulan-bulan."

Lebih lanjut bapak Musthafa menjelaskan factor penyebab terjadinya pembiayaan mudharabah bermasalah antara lain sebagai berikut:

"Penyebab pembiayaan bermasalah terjadi karena dua hal yaitu dari faktor internal (BMT) dan faktor eksternal (nasabah). Biasanya faktor eksternal ini penyebab utamanya yaitu usaha yang dijalankan nasabah mengalami kegagalan/macet, usaha mengalami kebangkrutan, nasabah kabur dan nasabah meninggal dunia dan tidak ada ahli waris yang ditinggali. Sering kali yang terjadi itu berupa gagal panen maupun hasil panen kurang mencukupi karena hama yang menyerang. Karena kegagalan tersebut pendapatan anggota berkurang dan menyebabkan pengembalian pembiayaan berpotensi jatuh tempo, sedangkan faktor internal terjadi karena adanya analisis pembiayaan yang dilakukan diawal kurang teliti."

Penyebab pembiayaan bermasalah bersumber dari factor internal dan eksternal pada KSPS BMT Logam Mulia bisa terjadi pada lembaga keuangan syariah dengan akad pembiayaan yang sama, Penelitian Arifah (2017) pada BMT Mitra Hasanah misalnya, mengungkapkan bahwa factor internal dan eksternal menjadi penyebab pembiayaan mudharabah bermasalah. Menariknya pada factor internal kinerja pegawai BMT MItra Hasanah dipertanyakan, mulai marketing lupa nagih, pergantian pegawai marketing dan penyaluran dana kurang jelas, untuk apa dana itu dipergunakan.

Meskipun prinsip kehati-hatian mutlak dilakukan KSPS BMT Logam Mulia dalam pembiayaan mudharabah, namun jangan sampai kehati-hatian tersebut menjadi penghambat perkembangan pembiayaan mudharabah sebagaimana terjadi pada bank syariah yang terhitung pembiayaan mudharabah lambat perkembangannya dalam lima tahun terakhir (Ismawati, 2018).

Bagaimanapun KSPS BMT Logam Mulia merupakan lembaga profit oriented, identifikasi penyebab pembiayaan mudharabah bermasalah dan berusaha meminimalisir masalah tersebut wajib dilakukan demi kemaslahatan anggota dan pengurus.

\section{Upaya Penyelesaian Pembiayaan Mudharabah Bermasalah pada KSPS BMT Logam Mulia Klambu}

Pembiayaan mudharabah merupakan produk utama yang dimiliki lembaga keuangan syariah, baik bank syariah maupun koperasi syariah. Untuk KSPS BMT Logam Mulia Klambu sebagaimana telah dijelaskan di atas, telah dilaksanakan 
dengan prinsip kehati-hatian. Efektifitas pembiayaan mudharabah sebetulnya mampu meningkatkan kinerja UMKM yang telah menjadi nasabah (Musdiana, 2015). Namun dalam proses pelaksanaannya bisa terjadi hal-hal yang tidak dinginkan, termasuk pembiayaan macet. Sehingga pihak KSPS BMT Logam Mulia Klambu telah memikirkan berbagai upaya untuk mengatasi permasalahn tersebut. Upaya penyelesaian secara umum yang dapat dilakukan pihak lembaga keuangan syariah dapat berupa rescheduling, reconditioning, restructuring, penyelesaian melalui jaminan serta hapus buku dan atau hapus tagih(Turmudi, 2016).

Lebih lanjut Manager KSPS BMT Logam Mulia Klambu, Bapak Musthafa menjelaskan langkah-langkah yang dilakukan sebagai berikut (Tyas, 2018):

“Untuk strategi penyelamatan terhadap pembiayaan bermasalah langkah yang kami utamakan yaitu dengan sistem kekeluargaan, kami akan bersilaturrahmi ke rumah nasabah penunggakan pembayaran pembiayaan, kami melakukan pemantauan dengan cara penagihan secara langsung kerumah nasabah tersebut. Selain penanganan dengan cara penagihan insentif pihak BMT juga melakukan penanganan melalui proses revitalisasi. Dengan adanya revitalisasi ini diharapkan nasabah tidak keberatan mengembalikan pembiayaan. Proses revitalisasi ini tidak kami terapkan untuk semua anggota, namun hanya pada anggota yang masih mempunyai itikad yang baik serta masih ada niat untuk melakukan pelunasan pembiayaan. Pada proses revitalisasi ini pihak BMT menggunakan 2 cara yaitu rescheduling artinya nasabah diberi kelonggaran waktu dan reconditioning artinya keringanan nasabah dalam pembayaran."

Dari uraian di atas dapat dipahami bahwa KSPS BMT Logam Mulia Klambu berusaha untuk melakukan penyelesaian pembiayaan mudharabah bermasalah melalui jalur kekeluargaan secara persuasif, maksudnya KSPS BMT Logam Mulia Klambu melakukan teguran secara lisan. Hal ini diamini oleh Hidayati selaku teller KSPS BMT Logam Mulia Klambu(Tyas, 2018):

"Sebagai karyawan BMT Logam Mulia langkah yang kami ambil apabila terdapat pembiayaan menunggak kami akan melakukan penagihan intensif secara continue."

Meskipun begitu $3 \mathrm{R}$ (rescheduling, reconditioning, restructuring) tetap akan dilakukan, jika jalur kekeluargaan mengalami kebuntuhan. Namun langkah ini bisa jadi menemui hambatan. KSPS BMT Logam Mulia Klambu dalam melakukan penyelamatan pembiayaan melalui proses reconditioning yaitu dengan cara merubah sebagian atau seluruh persyaratan pembiayaan yang tidak terbatas hanya pada perubahan jadwal pembiayaan, jangka waktu, dan persyaratan lainnya sepanjang tidak menyangkut perubahan maksimum pembiayaan. Pihak koperasi akan memberikan keringanan nasabah dengan cara menurunkan jumlah bagi hasil yang dibayarkan.

Langkah 3 R dilakukan KSPS BMT Logam Mulia dengan cara melihat watak nasabah. Apabila anggota pembiayaan masih mempunyai itikad yang baik dan masih mempunyai niat untuk melunasi pembiayaan. Pihak koperasi akan mempertimbangkan kembali mengenai perpanjangan waktu pelunasan. Karakter anggota yang pada dasarnya tidak memiliki itikad baik dan tidak kooperatif akan 
mempengaruhi proses penyelesaian pembiayaan mudharabah bermasalah menjadi tidak efisien (Primasatya, 2014).

Dalam penyelesaian pembiayaan bermasalah bagi anggota yang mempunyai karakter bandel maka KSPS BMT Logam Mulia Klambu melakukan hal-hal sebagaimana dijelaskan oleh bapak Musthafa sebagai berikut (Tyas, 2018):

"Apabila anggota nasabah masih dalam keadaan hidup dan merelakan agunan untuk dijual maka langkah yang akan akan ambil yaitu dengan cara eksekusi terhadap jaminan."

"Apabila nasabah anggota pembiayaan sudah tidak dapat melakukan pelunasan pembiayaan karena adanya alasan maka jalur yang kami tempuh yaitu dengan cara merelakan pembiayaan yang sudah tertunggak tersebut atau disebut dengan akad qardhu hasan. Namun pada kasus ini kami kelompokkan menjadi 2 yang berupa hapus buku dan hapus tagih. Hapus buku ini kami tempuh apabila usaha nasabah megalami pailit atau kegagalan usaha kami akan tetap menagih dengan cara angota tersebut membayar hutang pokonya. sedangkan pada hapus tagih ini pihak BMT sudah merelakan hutang tersebut apabila nasabah melarikan diri dan tidak bisa dihubungi dan nasabah sudah meninggal dunia dan tidak ada ahli waris yang meneruskan.

Sebetulnya pihak KSPS BMT Logam Mulia Klambu berusaha untuk tidak menggunakan eksekusi jaminan. Eksekusi jaminan dilakukan apabila anggota sudah tidak sanggup lagi membayar hutangnya atas pembiayaan mudharabah. Jaminan tersebut dijual dibawah tangan oleh anggota yang bersangkutan sebagai pemilik jaminan atau penjualan jaminan dengan cara lelang. Kemudian anggota melunasi sisa hutangnya kepada KSPS BMT Logam Mulia dari hasil penjualan. Apabila dengan sistem lelang hasil penjualan jika melebihi sisa hutang maka pihak KSPS BMT Logam mulia akan mengembalikan sisanya, namun apabila hasil penjualan lelang lebih sedikit maka sisa hutang akan tetap menjadi tanggungan anggota.

Berdasarkan hasil analisis diatas, upaya penyelesaian pembiayaan mudharabah bermasalah pada KSPS BMT Logam Mulia cabang Klambu sudah mempunyai system yang jelas. Upaya yang ditempuh oleh KSPS BMT Logam Mulia Cabang Klambu mengutamakan pendekatan secara damai (kekeluargaan), tidak melakukan system paksa dengan menggunakan debt collector yang mempunyai konotasi negatif. Pihak KSPS BMT Logam Mulia tidak menggunakan penyelesaian secara litigasi dikarenakan sampai saat ini belum menjumpai anggota yang tidak beritikad baik.

Sedangkan hapus buku merupakan pembiayaan macet yang tidak dapat ditagih lagi dihapusbukukan dari neraca dan dicatat pada rekening administratif. Praktek hapus buku pada lembaga keuangan yang lain bisa jadi hanya bersifat adminitratif sehingga penagihan terhadap debitur tetap dilakukan (Turmudi, 2016). Sedangkan proses hapus buku di KSPS BMT Logam Mulia dilakukan jika anggota koperasi meninggal dunia dan sudah tidak ada ahli waris yang ditinggali untuk melanjutkan pembayaran pembiayaan yang sudah menunggak atau pihak koperasi tidak mengetahui keberadaan anggotanya (melarikan diri). 


\section{PENUTUP}

Berdasarkan uraian di atas dapat disimpulkan bahwa Pertama, Praktek pembiayaan mudharabah di KSPS BMT Logam Mulia Klambu berjalan sebagaimana praktek mudharabah di lembaga keuangan syariah baik bak maupun koperasi syariah. Kedua, penyelesaian pembiayaan mudharabah bermasalah KSPS BMT Logam Mulia mengedepankan prinsip kekeluargaan dan berusaha menghindari jalur eksekusi jaminan atau jalur hukum. 


\section{DAFTAR PUSTAKA}

Al-Jambi, A. M. D. K. (2019). InsyaAllah HIdup Berkah Tanpa Riba. Jakarta: Iluvia Publishing.

Arifah, O. N. (2017). Analisis Pembiayaan Mudharabah Bermasalah Pada Bmt Mitra Hasanah Semarang. Jurisprudence, 7(1), 40-46.

Asiyah, B. N. (2015). Manajemen Pembiayaan Bank Syariah. Yogyakarta: Kalimedia.

Burhanuddin. (2013). Koperasi Syariah dan Pengaturannya di Indonesia. Malang: UINMaliki Press.

Friyanto. (2013). Pembiayaan Mudharabah, Risiko dan Penanganannya (Studi Kasus pada Bank BTN Kantor Cabang Syariah Malang). JURNAL MANAJEMEN DAN KEWIRAUSAHAAN, 15(2), 113-122. https://doi.org/10.9744/jmk.15.2.113-122

Ismawati. (2018). Mekanisme Dan Masalah Pembiayaan Mudharabah Pada Kantor Bank Panin Dubai Syariah Cabang Makassar. AL-MASHRAFIYAH: Jurnal Ekonomi, Keuangan, Dan Perbankan Syariah, 2(2).

Kolistiawan, B. (2014). Tinjauan Syariah Tentang Pembiayaan Bermasalah Di Perbankan Syariah. AN-NISBAH, 01(01).

Lestari, N. M., \& Setiawati. (2018). Strategi Penyelesaian Pembiayaan Bermasalah pada Akad Mudharabah di Bank Muamalat Indonesia serta Pengaruhnya Terhadap Penurunan Tingkat Non Performing Financing (NPF). Jurnal Ekonomi Islam, 9(1), 75-99.

Musdiana, R. N. (2015). Efektivitas Pembiayaan Mudharabah Dalam Meningkatkan Kinerja Umkm (Studi Kasus pada BMT NURUL JANNAH GRESIK) Rohmah. JEBIS, 1(1), 21-36.

Primasatya, A. (2014). Penanganan Pembiayaan Mudharabah Bermasalah Di Koperasi Syariah Kanindo Jatim. Jurnal Hukum, 6(8).

Qomar, M. N. (2018). Mudharabah Sebagai Produk Pembiayaan Perbankan Syariah Perspektif Abdullah Saeed. MALIA: Journal of Islamic Banking and Finance, 2(2), 201-210.

Turmudi, M. (2016). Manajemen Penyelesaian Pembiayaan Bermasalah Pada Lembaga Perbankan Syariah. Li Falah: Jurnal Studi Ekonomi Dan Bisnis Islam, I(1).

Tyas, L. N. R. (2018a). Hasil Wawancara dengan Pegawai KSPS BMT Logam Mulia Klambu. Kudus.

Tyas, L. N. R. (2018b). Sejarah KSPS BMT Logam Mulia. Grobogan.

Usanti, T. P., \& Thalib, P. (2016). Asas Ikhtiyati Pada Akad Pembiayaan Mudharabah Di Lingkungan Perbankan Syariah. Yurdika Fakultas Hukum Universitas Airlangga, 31(2), 297-320. 